\title{
ASUPAN PROTEIN MEMPENGARUHI TERJADINYA FRAILTY SYNDROME BERDASARKAN FRAILTY INDEX PADA USIA LANJUT DI KOTA MALANG
}

\author{
Tita Haryanti", Sri Sunarti**凶 , Justicia Puspa Luqyana ${ }^{* * *}$
}

\begin{abstract}
Abstrak
Aging atau penuaan merupakan sebuah proses yang merubah seorang manusia dewasa menjadi lanjut usia. Kebanyakan manusia dewasa adalah sehat dan dapat beraktivitas tanpa bantuan siapapun. Lalu, saat berusia lanjut akan mengalami penurunan fungsi fisiologis dan menjadi lebih rentan terhadap berbagai macam penyakit. Frailty syndrome sering dikorelasikan dengan munculnya kondisi patologis pada lanjut usia. Pada penelitian sebelumnya disebutkan bahwa malnutrisi dan imobilitas merupakan kunci dari berkembangnya frailty. Penelitian ini ingin membuktikan adanya hubungan antara pola makan yang dilihat dari asupan protein dengan frailty syndrome di Kota Malang. Penelitian ini menggunakan metode case control dengan populasi lansia di Kota Malang. Pengambilan sampel menggunakan metode purposive sampling. Frailty syndrome diukur menggunakan frailty index yang berisi 40 item. Asupan protein diukur dalam g/hari dan dalam asupan energi. Hasil uji korelasi Spearman menunjukkan hubungan yang signifikan antara jumlah protein dengan frailty syndrome. Namun, tidak ada hubungan yang signifikan antara asupan energi dengan frailty syndrome. Kesimpulan penelitian ini adalah asupan protein yang tinggi berhubungan dengan semakin kecilnya kejadian frailty syndrome. Namun, asupan energi tidak memiliki hubungan yang signifikan terhadap angka kejadian frailty syndrome.
\end{abstract}

Kata kunci: Frailty index, Frailty syndrome, Lanjut usia, Protein.

\section{THE RELATIONSHIP OF PROTEIN INTAKE AND FRAILTY SYNDROME IN ELDERLY PEOPLE MEASURED BY FRAILTY INDEX IN MALANG CITY}

\begin{abstract}
Aging is a process that transforms young adults into elderly people. Most of adults are healthy and able to do any activities without being help by other people. In elderly people, they are suffering from psychological fitness and are susceptible to any kind of disease. Frailty syndrome is often correlated with the emergence of pathological conditions in the elderly people. Previous researchers proved that malnutrition and immobility is the key to frailty syndrome. This research aims at proving the relationship between protein intake and frailty syndrome in Malang City. The method used was case control and the population were elderly people. The sample was collected by using purposive sampling method. Frailty syndrome was measured by using frailty index of 40 items. Protein intake was measured by g/day and by energy intake. Spearman Correlation test showed that there were significant relationship between protein intake and frailty syndrome. However, this test does not indicate significant relationship between energy intake and frailty syndrome. The research was concluded that high protein intake may decrease frailty syndrome, but energy intake may not significantly influence frailty syndrome.
\end{abstract}

Keywords: Elderly, Frailty Index, Frailty Syndrome, Protein.

* Departemen IImu Kesehatan Masyarakat dan Kedokteran Pencegahan, Fakultas Kedokteran, Universitas Brawijaya

** Divisi Geriatri dan Gerontologi, Departemen IImu Penyakit Dalam, Fakultas Kedokteran, Universitas Brawijaya

***Jurusan Ilmu Pendidikan Dokter, Fakultas Kedokteran, Universitas Brawijaya

$凶$ E-mail: sinartitan@rocketmail.com 


\section{Pendahuluan}

Aging atau menua merupakan sebuah proses yang merubah seorang manusia dewasa menjadi lanjut usia. Pada saat dewasa manusia tersebut sehat dan dapat beraktivitas tanpa bantuan siapapun menjadi seorang lanjut usia yang mengalami penurunan fungsi fisiologis dan menjadi lebih rentan terhadap berbagai macam penyakit. ${ }^{1}$ Aging dapat juga digambarkan sebagai proses akumulasi dari defisit yang memiliki manifestasi berbeda pada tiap individu, dengan pengaruh yang berbeda pada tiap sistem organ tergantung pada faktor intrinsik dan ekstrinsik. Aging diasosiasikan dengan disregulasi homeostasis atau homeodinamis yang bersifat progresif yang dapat membuat organisme menjadi kurang atau bahkan tidak adaptif lagi. $^{2}$

Pada tahun 2010, diperkirakan sebanyak 524 juta orang berusia di atas 65 atau lebih - sekitar delapan persen dari keseluruhan populasi dunia. Meskipun negara lebih berkembang memiliki profil lanjut usia dengan usia tertua, pertumbuhan dan populasi lanjut usia tetap tidak sebanyak pada negara yang kurang berkembang. Pada tahun 2010-2050, diperkirakan populasi lanjut usia akan meningkat lebih dari 250 persen pada negara yang kurang berkembang. ${ }^{3}$ Tercatat di Indonesia berdasarkan hasil Susenas tahun 2014 terdapat 20,24 juta lansia atau sekitar 8,03\% dari keseluruhan masyarakat Indonesia. Data tersebut menunjukkan peningkatan jika dibandingkan dengan hasil Sensus Penduduk tahun 2010 yang hanya sekitar 18,1 juta orang atau $7,6 \%$ dari total masyarakat Indonesia. ${ }^{4}$

Frailty syndrome sering dikorelasikan dengan munculnya kondisi patologis pada usia lanjut Termasuk di dalamnya adalah anemia, orthostasis, penurunan berat badan, sarkopenia, anoreksia, polifarmasi, gagal jantung kongestif, diabetes mellitus, osteopenia, hipovitaminosis vitamin D, defisiensi testosteron, kurangnya asupan protein, defisiensi pada protein trafficking, penurunan fungsi kognitif, inflamasi sehubungan dengan adanya peningkatan produksi sitokin, menurunnya regulatory peptides, dan lain-lain. ${ }^{5}$ Frailty syndrome terjadi pada $30 \%$ populasi di atas usia 80 tahun dan $7 \%$ pada populasi usia di atas 65 tahun dengan insiden pada perempuan lebih tinggi. ${ }^{6}$ Dalam sebuah penelitian pada 653 orang yang berusai 64-74 tahun di Inggris yang dilakukan dengan dengan menggunakan kriteria Fried, ditemukan prevalensi frailty sebesar $8,5 \%$ pada perempuan dan $4,1 \%$ pada laki-laki. Prevalensi meningkat seiring usia dengan tingkat $3,2 \%, 9,5 \%$, dan $25,7 \%$ untuk kelompok usia 65-70, 75-79, dan 85-89 tahun. ${ }^{7}$

Frailty syndrome kian mendapatkan perhatian di bidang gerontologi dan geriatri dalam 30 tahun terakhir ini. Frailty mempresentasikan kerapuhan multifaktorial terhadap beberapa stressor eksternal yang dikarenakan menurunnya fungsi fisiologis dan disregulasi pada beberapa sistem tubuh. Meski sedang mendapat perhatian, belum ada konsensus terkait pengukuran frailty. Meskipun demikian, terdapat pengukuran yang banyak digunakan yaitu yang pertama mengukur lewat model fenotip dan yang lainnya mengukur lewat akumulasi defisit kesehatan. Pengukuran pertama yaitu mengukur frailty dari lima manifestasi indikator spesifik, di antaranya penurunan berat badan yang tidak diinginkan, kelelahan, aktivitas fisik yang rendah, kelambanan berjalan, dan juga kelemahan. Pengukuran yang lainnya, frailty index mengukur frailty melalui proporsi dari defisit terhadap segala kemungkinan defisit kesehatan, fungsional, dan domain psikososial pada tiap-tiap individu. Berbeda dengan model fenotip, frailty index lebih berfokus pada penurunan psikososial dan 
fungsi fisik sehingga menjadikannya pengukuran yang menjanjikan untuk penuaan biologis.

Hasil penelitian Roschelle dan Heuberger (2013) menyebutkan bahwa malnutrisi dan imobilitas merupakan kunci berkembangnya frailty. ${ }^{5}$ Para usia lanjut cenderung mengalami malnutrisi dikarenakan kecepatan metabolik, massa otot tanpa lemak, fungsi gastrointestinal, persepsi sensoris, dan homeostasis. Malnutrisi menyebabkan meningkatnya penurunan massa otot tanpa lemak. Banyak penelitian yang menginvestigasi PEM (protein energy malnutrition), mikronutrisi, dan keseluruhan status nutrisi dari usia lanjut yang mengamati frailty dengan tujuan menyajikan rekomendasi untuk mencegah frailty.

\section{Women's Health Initiative}

Observational Study menunjukkan hasil yang signifikan adanya asosiasi antara asupan protein dan frailty. ${ }^{5}$ Didukung dengan hasil penelitian Kobayashi et al. (2013) yang menyebutkan bahwa campuran dari beberapa asam amino esensial memberikan dampak pada sintesis protein otot dan juga meningkatkan fungsional fisik tubuh. ${ }^{8}$ Gangguan pada protein sintesis dan stres oksidatif dapat menyebabkan kehilangan otot karena usia, mengindikasikan bahwa terdapat hubungan antara asam amino dengan frailty.

Sementara itu, Blum menyatakan bahwa derajat kesehatan dipengaruhi oleh 4 faktor yaitu faktor lingkungan, perilaku masyarakat, pelayanan kesehatan, dan keturunan. ${ }^{9}$ Termasuk dalam perilaku masyarakat adalah gaya hidup mereka sehari-hari, contohnya pola makan tiap individu. Faktor perilaku masyarakat ini cenderung bisa diubah (modifiable) sehingga memungkinkan untuk diusahakan agar tercapai kondisi sehat.

Pencegahan akan jauh lebih efektif khususnya dalam hal biaya dan sebaiknya menjadi pertahanan pertama. Berdasarkan penjelasan di atas, dapat disimpulkan bahwa nutrisi berpengaruh pada kesehatan tubuh manusia secara keseluruhan. Oleh karena itu, penelitian ini ingin membuktikan adanya hubungan antara asupan protein dengan frailty syndrome di Kota Malang.

\section{Bahan dan Metode}

Desain dari penelitian ini adalah casecontrol karena ingin melihat hubungan antara faktor risiko yaitu berupa asupan protein dengan angka kejadian frailty. Hasil yang didapatkan selanjutnya dianalisis secara statistik untuk mendapatkan korelasi antar variabel. Populasi penelitian adalah populasi lanjut usia yang berada di masyarakat. Pengambilan sampel dilakukan secara purposive sampling dari komunitas Karang Wredha di lima kecamatan di kota Malang (Kecamatan Klojen, Kecamatan Lowokwaru, Kecamatan Kedungkandang, Kecamatan Sukun, dan Kecamatan Blimbing). Populasi yang terpilih kemudian mengisi kuesioner dan dilakukan pemeriksaan kondisi frailty.

Besar sampel ditentukan secara proposional pada 5 kecamatan di Kota Malang dengan rincian sebagai berikut pada Tabel 1.

Tabel 1. Jumlah sampel tiap kecamatan

\begin{tabular}{llc}
\hline No & Kecamatan & Besar Sampel \\
\hline 1 & Klojen & 52 \\
2 & Lowokwaru & 62 \\
3 & Sukun & 69 \\
4 & Blimbing & 69 \\
5 & Kedungkandang & 27 \\
\hline & Jumlah & 279 \\
\hline
\end{tabular}

Pada penelitian ini didapatkan responden sejumlah 195 orang. Hal ini disebabkan oleh beberapa hal di antaranya, responden yang tidak memenuhi kriteria inklusi, data antropometri yang tidak 
lengkap, dan juga data pola makan yang tidak lengkap. Selain itu, juga terdapat keterbatasan dalam hal jumlah sumber daya manusia, waktu, dan biaya. Jumlah responden di tiap-tiap kecamatan dijabarkan dalam Tabel 2. .

Tabel 2. Jumlah responden tiap kecamatan

\begin{tabular}{llc}
\hline No. & Kecamatan & Besar Sampel \\
\hline 1 & Blimbing & 49 \\
2 & Kedungkandang & 24 \\
3 & Klojen & 22 \\
4 & Lowokwaru & 39 \\
5 & Sukun & 61 \\
\hline & Jumlah & 195 \\
\hline
\end{tabular}

Penelitian ini dilakukan di Kecamatan Klojen, Lowokwaru, Kedungkandang, Sukun dan Blimbing, Kotamadya Malang pada bulan Mei 2017 dengan variabel tergantung berupa frailty (robust, pre-frail, dan frail) dan variabel bebas berupa asupan protein.

Kriteria inklusi yang digunakan adalah subjek harus berusia $\geq 60$ dan menandatangai informed consent sebagai bentuk kesediaan mengikuti penelitian. Kriteria eksklusi yang digunakan adalah subjek tidak dapat mengikuti penelitian karena gangguan mobilisasi yang berat seperti gangguan sendi berat dan sakit akut.

Definisi operasional yang digunakan dalam penelitian ini adalah sebagai berikut: 1. Frailty syndrome. Kumpulan dari beberapa gejala yang bila didapatkan pada individu maka individu tersebut menjadi lebih rentan terhadap stress dari lingkungan sekitarnya dan memiliki kemungkinan yang lebih besar untuk sakit, jatuh, institusionalisasi dan disabilitas. Kondisi frailty diukur menggunakan kriteria Frailty Index (FI) 40 item. ${ }^{10}$

2. Robust. Subjek disebut sebagai robust apabila skor $\leq 0,08$ dengan menggunakan kriteria Fl 40 item di atas.
3. Pre-frail. Subyek disebut sebagai pre-fraill apabila skor $>0,08 \quad-\quad<0,25$ dengan menggunakan kriteria FI 40 item di atas.

4. Frail. Subyek disebut sebagai frail apabila skor $\geq 0,25$ dengan menggunakan kriteria $\mathrm{FI}$ 40 item di atas.

5. Asupan protein. Asupan protein subjek dihitung dalam rentang waktu selama tiga bulan. Konsumsi protein tersebut dilihat menggunakan SQ-FFQ (semiquantitative food frequency quisionnaire) dengan prosedur sebagai berikut: (a). Responden diminta untuk mengidentifikasi seberapa sering mengkonsumsi makanan yang terdapat di dalam daftar makanan yang telah disediakan. (b). Responden memilih kategori yang tepat untuk konsumsi makan, dan kemudian dicatat berapa kali makanan tersebut dikonsumsi. (c). Responden memilih jumlah porsi berdasarkan jenis makanan yang dimakan: kecil, sedang, besar. (d). Mengkonversikan jumlah frekuensi yang dikonsumsi ke dalam jumlah rata-rata per hari 11.

Asupan protein ditinjau dari dua aspek, meliputi: (a) Asupan protein. Subjek dihitung asupan proteinnya dalam sehari dalam gram. (b). Asupan energi. Subjek dihitung asupan energi menggunakan \% Angka Kecukupan Gizi (AKG). Subjek dihitung tingkat kecukupan energi dan zat gizi menurut Depkes $\mathrm{Rl}, 1996$ yang terbagi menjadi 5 kategori meliputi: (1). Defisit tingkat berat. Subjek dikatakan mengalami defisit tingkat berat jika memenuhi $<70 \%$ AKG. (2). Defisit tingkat sedang. Subjek dikatakan mengalami defisit tingkat sedang jika memenuhi $70-79 \%$ AKG. (3). Defisit tingkat ringan. Subjek dikatakan mengalami defisit tingkat ringan jika memenuhi 80-89\% AKG. (4). Normal. Subjek dikatakan normal apabila memenuhi 90-119\% AKG. (5). Kelebihan. Subjek dikatakan berlebihan apabila memenuhi $>120 \%$ AKG.

Instrumen yang digunakan pada penelitian ini adalah semiquantitative food 
frequency quisioner (SQ FFQ) yang menilai asupan zat gizi tertentu (protein) dan timbangan untuk mengukur berat badan.

Penelitian ini menggunakan data primer yang berasal dari observasi langsung kepada responden dengan mewawancarai responden dengan kuisioner gizi dan mencatat hasil wawancara tersebut. Pengukuran berat badan dilakukan dengan menggunakan timbangan yang kemudian akan diolah untuk mengetahui tingkat kecukupan energi menggunakan AKGprotein yang diolah menggunakan Nutrisurvey Indonesia tahun 2005.

Pengumpulan data dilakukan mulai tanggal 6-31 Mei 2017. Pengambilan di Kecamatan Blimbing dilaksanakan selama 4 hari, yaitu 18, 23-25 Mei 2017. Pada tanggal 18 Mei 2017, pengambilan data dilaksanakan di Balai RW 2 Kecamatan Ksatrian Malang pada pukul $08.00-10.00$. Pada tanggal 23-24 Mei 2017 pengambilan data dilakukan dengan home visit dari pukul 15.30 - 17.00. Pengambilan data terakhir untuk Kecamatan Blimbing pada tanggal 25 Mei 2017 dilaksanakan di panti werdha pada pukul 08.00 - 12.00. Pengambilan data Kecamatan Klojen dilaksanakan pada tanggal 20 Mei 2017 di Kantor Kecamatan Klojen pada pukul 09.00 - 11.00. Pengambilan data di Kecamatan Kedungkandang di senam rutin karang werdha Kecamatan Kedungkandang pada pukul 07.00 - 12.00. Pengambilan data di Kecamatan Lowokwaru dilaksanakan selama 3 hari. Hari pertama pada tanggal 8 Mei 2017 di rumah salah satu lansia pada pukul 08.00 - 12.00. Pengambilan data hari kedua dilaksanakan pada tanggal 21 Mei $2017 \mathrm{di}$ posyandu lansia Kecamatan Lowokwaru pada pukul 07.30 - 11.00. Pengambilan data hari ketiga dilaksanakan di panti werdha Kecamatan Lowokwaru pada pukul 08.00 12.00. Pengambilan data di Kecamatan Sukun dilaksanakan di Kantor Kecamatan Sukun pada 6 Mei 2017 pukul 08.30 - 11.00 dan 31 Mei 2017 pada pukul 08.00 - 12.00 .

Metode uji statistik yang digunakan adalah uji hipotesis komparatif Spearman untuk menguji hipotesis asosiatif kedua variabel.

\section{Hasil}

Pada penelitian yang telah dilaksanakan, didapatkan total sebanyak 195 responden yang memenuhi kriteria penelitian. Responden yang tidak memiliki kelengkapan data (tidak ada data berat badan, tidak lengkap dalam pengisian kuisioner pola makan), maka tidak diikutsertakan dalam perhitungan penelitian. Karakteristik umum responden dapat dilihat pada Tabel 3.

Tabel 3. Karakteristik umum sampel $(n=195)$

\begin{tabular}{lcc}
\hline Karakteristik & Jumlah & Persentase \\
\hline $\begin{array}{l}\text { Jenis kelamin } \\
\text { Laki-laki }\end{array}$ & 43 & $22 \%$ \\
$\begin{array}{l}\text { Perempuan } \\
\text { Kerapuhan }\end{array}$ & 152 & $78 \%$ \\
$\quad$ Frail & & \\
Pre-frail & 28 & $14 \%$ \\
Robust & 125 & $64 \%$ \\
\%AKG & 42 & $22 \%$ \\
Defisit berat & 128 & $66 \%$ \\
Defisit ringan & 21 & $11 \%$ \\
Defisit sedang & 13 & $7 \%$ \\
Normal & 11 & $5 \%$ \\
$\quad$ Kelebihan & 22 & $11 \%$ \\
\hline
\end{tabular}

Terdapat sebanyak 152 responden perempuan $(78 \%)$ dan sebanyak 43 responden laki-laki (22\%). Responden dengan derajat kerapuhan frail tercatat sebanyak $28(14 \%)$, derajat kerapuhan prefrail sebanyak 125 (64\%), dan derajat kerapuhan robust sebanyak 42 (22\%). Responden dengan \% AKG mengalami defisit berat terdapat sebanyak $128(66 \%)$, defisit ringan sebanyak 21 (11\%), defisit 
sedang sebanyak $13(7 \%)$, normal sebanyak $11(5 \%)$, dan kelebihan sebanyak $22(11 \%)$.

Data dari variabel bebas dan variabel tergantung kemudian untuk melihat distribusi frekuensinya. Karakteristik sampel disajikan dalam median (minimum - maximum) untuk variabel kontinu dan dalam persen untuk variabel kategorikal.

Tabel 4. Frailty dan angka kecukupan gizi $(n=195)$

\begin{tabular}{llll}
\hline & $\begin{array}{l}\text { Frail } \\
(\mathrm{n}=28)\end{array}$ & $\begin{array}{l}\text { Prefrail } \\
(\mathrm{n}=145)\end{array}$ & $\begin{array}{l}\text { Robust } \\
(\mathrm{n}=42)\end{array}$ \\
\hline $\begin{array}{l}\text { Asupan protein } \\
\text { (g/hari) }\end{array}$ & 27,3 & 29 & 37,4 \\
$\begin{array}{l}\text { Angka kecukupan } \\
\text { gizi }\end{array}$ & & & \\
$\begin{array}{l}\text { Defisit berat } \\
\text { Normal }\end{array}$ & 11,3 & 55,3 & 16,4 \\
Kelebihan & 0,5 & 3,6 & 1,5 \\
\hline
\end{tabular}

Berdasarkan Tabel 4 dapat dilihat lansia yang mengalami frail $(n=128)$ asupan protein per harinya hanya berkisar sekitar 27,3 g. Untuk lansia dengan derajat kerapuhan pre-frail $(n=145)$, asupan protein per hari berkisar sekitar $29 \mathrm{~g}$. Untuk lansia dengan derajat kerapuhan robust $(n=42)$, asupan protein per hari berkisar sekitar 37,4 g.

Sementara itu, asupan energi yang dihitung berdasarkan \% AKG, responden yang memiliki derajat frail dan mengalami defisit terdapat sejumlah 22 orang $(11,3 \%)$, normal 1 orang $(0,5 \%)$, dan kelebihan 5 orang $(2,6 \%)$. Responden yang memiliki derajat prefrail dan mengalami defisit sejumlah 108 orang $(55,3 \%)$, normal sejumlah 7 orang $(3,6 \%)$, dan kelebihan sejumlah 10 orang $(5,1 \%)$. Pada responden yang memiliki derajat robust mengalami defisit sejumlah 32 orang $(16,4 \%)$, normal sejumlah 3 orang $(1,5 \%)$, dan kelebihan sejumlah 7 orang $(3,6 \%)$.

Pengujian hubungan asupan protein per hari dengan frailty syndrome yang diukur menggunakan kriteria frailty index (FI) dilakukan menggunakan korelasi Spearman dengan hasil $p=0,000$. Pengujian hubungan asupan energi dengan frailty syndrome yang diukur menggunakan kriteria frailty index $(\mathrm{FI})$ dilakukan menggunakan korelasi Spearman dengan hasil sebesar $p=0,309$.

\section{Pembahasan}

Nutrisi merupakan faktor penyumbang yang krusial dalam kompleks etiologi dari frailty dan merupakan pemeran penting dalam sarkopenia, sebagaimana nutrisi berperan sebagai sumber energi dan zat esensial yang dibutuhkan oleh tubuh untuk mempertahankan dan menjalankan segala organ dan fungsi-fungsinya termasuk di dalamnya otot. ${ }^{12}$ Hasil penelitian Rahi et al. (2015) menyebutkan bahwa asupan protein dan asupan energi berperan dalam pencegahan penurunan fungsional dengan cara menjaga kekuatan otot. ${ }^{13}$

Dari hasil penelitian menunjukkan bahwa ada pengaruh yang signifikan antara jumlah asupan protein yang dikonsumsi oleh lansia dengan frailty syndrome. Hal ini sesuai dengan penelitian yang dilakukan oleh Bartali et al. (2006) yang menyatakan bahwa asupan yang rendah dari total protein secara signifikan berhubungan dengan frailty. ${ }^{14}$ Penelitian Beasley et al. pada tahun 2010 menunjukkan adanya efek dari sumber protein (protein hewani) atau kualitas protein (asam amino esensial) pada frailty pada studi cohort dengan skala besar, dan menyatakan bahwa adanya hubungan antara asupan protein yang tinggi dengan rendahnya kejadian frailty. ${ }^{15}$

Pada usia lanjut, beberapa perubahan fisiologis dapat dipastikan terjadi, salah satunya berkurang massa otot yang tidak terkait dengan penyakit. Selain itu, perubahan fisik lainnya yang terjadi pada orang usia lanjut dapat diakibatkan dari perubahan otot. Sebagai contoh, berkurangnya massa otot dikarenakan 
penuaan akan menyebabkan perubahan komposisi tubuh yaitu meningkatnya persentase lemak tubuh. Mekanisme fundamental dari pengaruh asupan protein dengan perubahan otot dan juga fisik pada tubuh lainnya adalah stimulasi dari protein otot yang didapat dari asam amino yang terabsorbsi. Protein otot secara khusus responsif terhadap asam amino. Sintesis protein otot distimulasi oleh dosis tunggal asam amino sebanyak $15 \mathrm{~g}$ lebih banyak daripada hormon anabolik, termasuk testosteron, insulin, dan hormon pertumbuhan. Ditemukan adanya hubungan dose-dependent antara asam amino dengan sintesis protein. Pada dosis rendah asupan asam amino, usia lanjut kurang responsif daripada orang dewasa. Berkurangnya responsifitas pada lansia bisa diatasi dengan pemberian dosis asam amino yang lebih tinggi. Maka dari itu, asupan protein yang lebih tinggi dibutuhkan pada lansia untuk mendapatkan efek stimulasi yang sama untuk sintesis protein otot pada orang dewasa. Kebutuhan atas protein utuh yang lebih tinggi ini yang menjadi salah satu dasar dari keuntungan protein asupan pada usai lanjut. 16

Pada penelitian yang dilakukan oleh $\mathrm{J}$. Bauer et al. menyatakan bahwa terdapat bukti baru yang menyatakan tingginya asupan protein akan menguntungkan untuk kesehatan, kesembuhan dari penyakit, dan juga mempertahankan fungsionalitas dari lansia. ${ }^{17}$ Sejalan dengan yang dikatakan Wolfe et al., kebutuhan akan asupan protein yang lebih tinggi ini dikarenakan menurunnya respons anabolik terhadap asupan protein asupan pada lansia. ${ }^{16}$ Protein yang tinggi juga dibutuhkan untuk mengatasi inflamasi dan kondisi katabolik yang sering berkaitan dengan penyakit akut dan kronis yang umumnya terjadi pada usia tua.

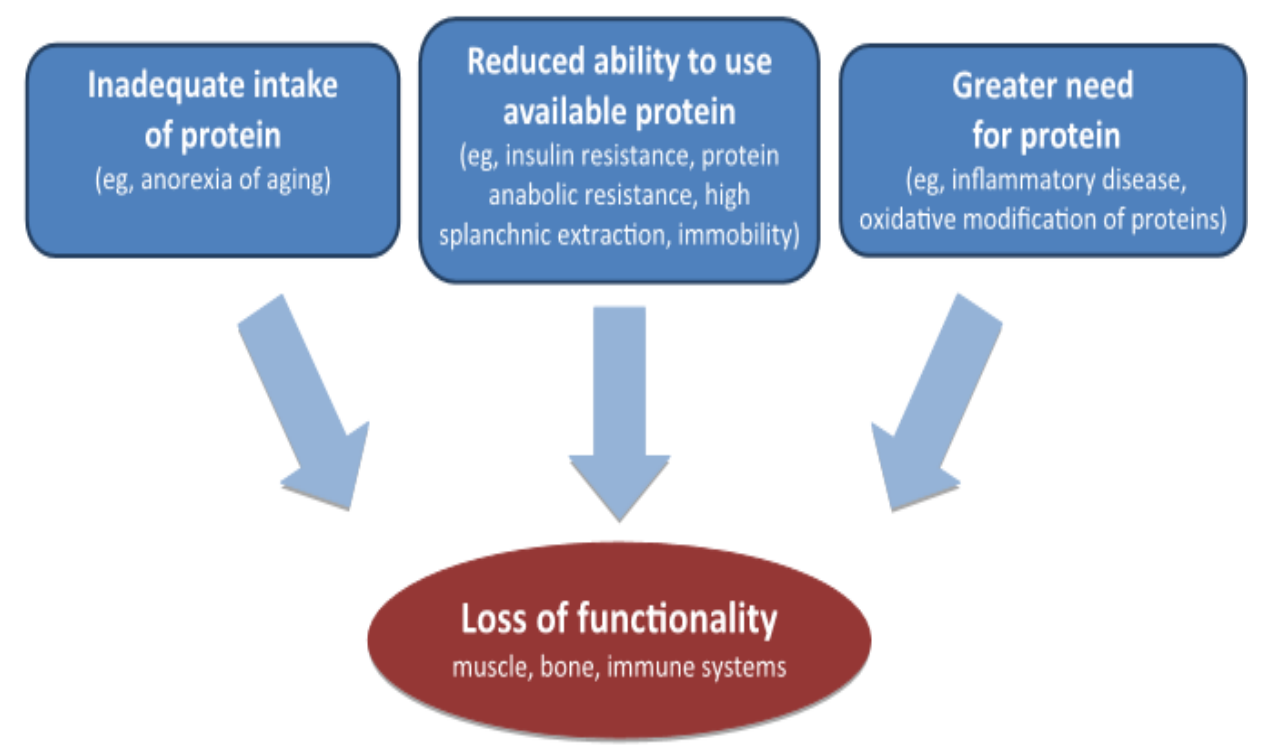

Gambar 1. Penyebab defisit protein pada lansia ${ }^{18}$

Pada Gambar 1 menunjukkan beberapa penyebab defisit protein pada usia lanjut. Defisit dari kebutuhan protein pada lansia bisa mengarah pada penurunan massa tubuh, khususnya massa otot. Sebagai konsekuensinya, usia lanjut lebih rentan terhadap sarkopenia dan osteoporosis dari pada usia muda. Selanjutnya sarkopenia dan osteoporosis dapat menyebabkan kondisi yang lebih buruk pada lansia berupa: jatuh 
dan fraktur, disabilitas, hilangnya kemandirian, dan berujung pada kematian.

Penelitian yang dilakukan oleh Bennefoy et al. (2015) menyebutkan bahwa kandungan asam amino pada protein dapat menstimulasi sintesis protein. ${ }^{19}$ Sebagian besar dari efek yang meningkatkan stimulasi sintesis protein setelah makan adalah asam amino. Asupan protein per hari dapat menstimulasi sintesis protein dan dapat menghambat pemecahan protein pada orang dewasa dan juga usia lanjut sehingga keseimbangan protein dapat tercapai. Selain itu, banyak juga penelitian yang menyebutkan bahwa protein atau asam amino berfungsi untuk meningkatkan fractional synthesis rate (FSR) dari protein otot.

Asupan protein yang tidak mencukupi juga berpengaruh pada menurunnya fungsi fisik dan juga kormorbiditas. Asupan protein yang lebih tinggi berguna dalam mencegah risiko dari efek yang tidak diinginkan (adverse event) dan juga untuk mencegah frailty. Pada studi longitudinal yang dilakukan selama sepuluh tahun, Vellas et al. melaporkan perempuan dengan asupan protein yang tinggi memiliki lebih sedikit permasalahan kesehatan.

Energi yang dibutuhkan tiap individu didapatkan dari asupan makanannya yang mengandung banyak gizi. Angka Kecukupan Gizi (AKG) adalah taraf konsumsi zat-zat gizi esensial, yang berdasarkan pengetahuan ilmiah dinilai cukup untuk memenuhi kebutuhan hampir semua orang sehat. AKG yang dianjurkan didasarkan pada patokan berat badan untuk masing-masing kelompok, jenis kelamin, aktivitas fisik, dan kondisi fisiologis tertentu seperti kehamilan dan menyusui. AKG untuk protein yang merupakan jumlah kebutuhan berbeda akan berbagai asam amino yang terdapat dalam proporsi yang berbeda di dalam berbagai jenis makanan. Pada kebanyakan zat gizi, pencenaan dan atau absorbsinya tidak komplit, sehingga AKG yang dianjurkan harus sudah memperhitungkan bagian zat gizi yang tidak diabsorpsi ini.

Berdasarkan hasil penelitian, hubungan antara AKG protein dengan frailty syndrome tidak menunjukkan angka yang signifikan. Dari hasil penelitian didapatkan, bahwa lansia di Kota Malang sebagian besar mengonsumsi zat gizi protein kurang dari AKG yang dianjurkan. Hal ini senada dengan penelitian yang telah dilakukan oleh Setiati, 2007 yang menyatakan penelitian yang telah dilakukan di multisenter di 15 propinsi di Indonesia mendapatkan bahwa $47 \%$ usia lanjut mengonsumsi protein kurang dari $80 \%$ AKG. ${ }^{20}$

Pada penelitian yang dilakukan oleh Rahi et al. pada tahun 2016 menyatakan tidak ada asosiasi antara asupan energi dengan frailty. ${ }^{21}$ Pada penelitian sebelumnya, Rahi et al., juga tidak menemukan adanya hubungan yang kuat antara asupan energi dengan penurunan fungsional pada usia lanjut yang mengalami diabetes. ${ }^{13} \mathrm{Hal}$ ini dikarenakan asupan energi juga dipengaruhi oleh faktor lain yaitu usia, jenis kelamin, level aktivitas fisik, dan juga adanya penyakit kronis.

Pada penelitian sebelumnya yang dilakukan oleh Rahi et. al. pada tahun 2015, menyebutkan bahwa asupan energi yang cukup tidak berhubungan dengan preservasi dari kekuatan otot. ${ }^{13} \mathrm{Hal}$ ini tidak sesuai dengan asumsi awal bahwa asupan protein dan asupan energi yang adekuat akan mencegah penurunan fungsional dengan cara menjaga kekuatan otot. Kemudian hal ini memunculkan spekulasi bahwa asupan energi mungkin bekerja pada pencegahan penurunan fungsional, namun tidak dengan cara mencegah berkurangnya kekuatan otot.

Perlu diperhatikan bahwa dalam penetapan AKG digunakan patokan berat badan tertentu, misalnya pria dewasa $62 \mathrm{~kg}$ dan perempuan dewasa $55 \mathrm{~kg}$. Bila hasil survei menunjukkan bahwa rata-rata berat 
badan menyimpang dari patokan berat badan yang digunakan, perlu dilakukan penyesuaian terhadap angka kecukupan. Demikian pula penyesuaian angka kecukupan perlu dilakukan bila asam amino dan nilai kecernaan hidangan berbeda dengan nilai yang digunakan dalam penetapan AKG yang dianjurkan. Namun, pada penelitian ini tidak dilakukan penyesuaian terhadap angka kecukupan sehingga faktor ini yang memungkinkan menjadi penyebab tidak signifikannya hubungan antara \% AKG -protein dengan frailty.

Terdapat beberapa keterbatasan dalam penelitian ini, yang pertama kecilnya jumlah sampel pada kelompok frail dan robust sehingga membatasi kekuatan dari studi statistik. Kedua, pengunaan kuesioner SQFFQ dengan rentang waktu tiga bulan memungkinan adanya bias memori pada responden.

\section{Kesimpulan}

Terdapat pengaruh antara asupan protein dengan frailty syndrome. Semakin tinggi asupan protein, maka semakin kecil kemungkinan untuk mengalami frail. Namun tidak terdapat hubungan yang cukup kuat antara asupan energi yang dilihat dari AKG dengan frailty syndrome.

Secara keseluruhan, total asupan protein lebih berpengaruh daripada total asupan energi terhadap penundaan proses aging dan secara khusus pada frailty, yang nantinya akan mengarah pada penurunan fungsional.

\section{Saran}

Masyarakat khususnya yang berusia lebih dari 60 tahun diharapkan lebih memperhatikan pola makanannya, utamanya terkait makanan yang memiliki sumber protein yang tinggi dengan mencanangkan program penyuluhan gizi bagi usia lanjut sesuai dengan hasil AKG.

Untuk penelitian ke depannya, guna meminimalisir bias memori responden pada saat melakukan wawancara nutrisi, rentang waktu pertanyaan pada kuisioner SQ-FFQ bisa dipersingkat, serta memperbesar jumlah sampel utamanya untuk kategori frail dan robust.

\section{Daftar Pustaka}

1. Halter JB. 2009. Hazard's Geriatric Medicine and Gerontology. $6^{\text {th }}$ Edition. United States: The McGraw Hill Companies. P. 3.

2. Fulop $T$, Larbi A, Witkowski JM, McElhaney J, Loeb $M$, Mitnitski $A$, Pawalec G, et al. Aging, Frailty, and AgeRelated Disease. Biogerontology. 2010; 11:547-563.

3. WHO. Global Health and Aging. $N I H$ Publication. 2011.

4. Badan Pusat Statistik, Statistik Penduduk Lanjut Usia. Jakarta: Badan Pusat Statistik2015.

5. Heuberger RA. The Frailty Syndrome: A Comprehensive Review. Journal of Nutrition in Gerontology and Geriatrics. 2011; 30(4):315-368.

6. Gessal J. dan Utari W. Latihan Fisik pada Frailty Syndrome. Jurnal Biomedik. 2013; 5(3):131-141.

7. Clegg $A$ and Young J. The Frailty Syndrome. Clinical Medicine. 2011; 11(1):72-75.

8. Satomi K, Asura K, Suga H, Sasaki S and the Three-generation Study of Women on Diets and Health Study Group. High Protein Intake Is Associated with Low Prevalence of Frailty Among Old Japanese Women: A Multicenter Cross-Sectional Study. Nutrition Journal. 2013;12:124. 
9. Notoatmodjo S. Promosi Kesehatan dan IImu Perilaku. Jakarta: Rineka Cipta. 2007.

10. Mitniski A, Song X, Rockwood K. The Estimation of Relative Fitness and Frailty in Community Dwelling Older Adults

12. Goisser S, Guyonet S, and Volkert D. The Role of Nutrition in Frailty: An Overview. The Journal of Frailty \& Aging. 2016; 5(2):74-77.

13. Bena R, Morais JA, Gaudreau P, Pyette $H$, Shatenstein B. Energy and Protein Intakes and The Association with $A$ Decline in Functional Capacity Among Diabetic Older Adults From The Nuage Cohort. Springer-Verlag. 2015.

14. Bartali B, Frongillo EA, Bandinelli S, Lauretani $F$, Semba RD, Fried LP, Ferrucci L. Low Nutrient Intake is an Essential Component of Frailty in Older Persons. The Journals of Gerontology: Series A. 2006; 61(6):589-593.

15. Beasley JM, La Croix AZ, Neuhouser ML, Huang $Y$, Tinker L, Woods N, Michael $Y$, Curb JD, Prentice RL. Protein Intake and Incident Frailty in The Women's Health Initiative Observational Study. J Am Geriatr Soc. 2010; 58(6):1063-71.

16. Wolfe RR, Sharon L. Miller, Kevin B. Miller. Optimal Protein Intake in The Elderly. Clinical Nutrition, 2008, 27: 675684

17. Julia B, Diekman R, Kaiser MJ, Bauer JM, Uter W, Siebe CC, and Volkert D. Distribution but Not Amount of Protein Intake is Associated with Frailty: A CrossSectional Investigation in The Region of Numberg. Nutrition Journal. 2013; 12:109.

18. Bauer J, Biolo G, Cederholm T, Cesar M, Cruz-Jentoft AJ, Morley EJ, Phillips S, et al. Evidence-Based Reccomendation for Optimal Dietary Protein in Older Peolple: A position Paper from the PROT-AGE Study Group. JAMDA. 2013;14:542-559.
Using Self-Report Database. J Gerontol A Biol Sci Med Sci. 2004;59: M627-32.

11. Food Frequency Questionnaire (FFQ). International Dietary Data Expansion Project 2015-2018.

19. Bonnefoy M, Berrut G, Lesourd B, Ferry M, Gilbert T, Guérin O, Hanon O, Jeandel $C$, Paillaud $E$, Raynaud-Simon A, Ruault G, Rolland Y. Frailty and Nutrition: Searching for Evidence. J Nutr Health Aging. 2015; 19(3):250-7.

20. Setiati S. Geriatric Medicine, Sarkopenia, Frailty dan Kualitas Hidup Pasien Usia Lanjut: Tantangan Masa Depan Pendidikan, Penelitian dan Pelayanan Kedokteran di Indonesia. Jakarta: Buku Prosiding Temu IImiah Geriatri. 2013.

21. Bena R, Colombert Z, Magali Gonzalez-Colaco Harmand, Dartigues JF, Boirie Y, Letenneur L, Feart C. Higher Protein but Not Energy Intake is Associated with A Lower Prevalence of Frailty Among Community-Delling Older Adults in The Frech Three-City Cohort. Jamda. 2016; 7: 672.e7-672.e11. 